\title{
Access to Preferential Loans for Poverty Reduction and Rural Development: Evidence from Vietnam
}

\author{
Lan Thanh Nguyen, \\ Anh Pham Hoai Nguyen, \\ Steven van Passel, \\ Hossein Azadi, and \\ Philippe Lebailly
}

\begin{abstract}
Preferential loans play an important role in the process of reducing poverty in developing countries. Considering the data set from the 2010 Vietnam Household Living Standards Survey, we aim to examine the influential factors in probability of households getting access to preferential loans. Additionally, we analyze the determinants of household income in association with the loans by applying a quintile regression model. Our results show that ethnicity-related factors have the largest marginal effect on the access to preferential loans. The results from the quantile regression model demonstrate that, at the lower quantiles of household income, the debt factor has deeper impact on the borrowing group.
\end{abstract}

Keywords: access to finance, economic growth, economic policy, household income, poverty reduction

JEL Classification Codes: $\mathrm{H}, \mathrm{O} 1, \mathrm{O} 2$

Poverty reduction is a top priority not only of governments, but also of international organizations (Driscoll and Evans 2005; Swartza 1998; Winter 2002). At the same time, it obvious that the majority of the poor, who live in rural areas, are also food-insecure (UNDP 2014). The mission set by the World Bank in 2001 to help low-income countries and their development partners illustrated the impact of their common efforts to battle against poverty as the first goal among the eight Millennium Development Goals (MDGs). In order to achieve this goal by 2015, the United Nations called for the linkages of every nation to place it as one of the most important targets in their national developing strategies (World Bank 2001).

One important factor for poverty reduction is to provide the poor with sufficient funds along with the guidance to enable them to conduct their entrepreneurial activities, which can potentially increase their income, improve their living standards, and sustainably get rid of poverty. David Craig and Doug Porter (2003), Manh Hao Quach (2005), Muhammad Yunus (2003), and John Weiss (2008) present evidence of a causal relationship between microfinance, including preferential loans, and household income, such as diff-in-diff estimators. Shortage of capital is the main reason that limits the low-income groups from increasing and diversifying their incomes (Yunus 2003), building assets, and reducing and mitigating risks, making choices, and planning for a better future. Microcredit includes various credit programs, such as financial services to export enterprises, specialized industries, and poor individuals (Dhakal 2004). In this study, we define preferential loan as a kind of microfinance program that provides financial services to poor individuals, households, and their micro-enterprises. Such a financial source with a wide and flexible range, and with appropriate services tailored to the preference and needs of the poor, can be regarded as an imperative tool for ending poverty. 
Several studies ( Dhakal 2004; Hamilton 1970) evidence the linkage between microfinance programs and the achievement of at least five MDGs: namely, poverty and hunger eradication, public infrastructure, education improvement, health outcomes for women and children, and women's empowerment. Ozgur Kaya, Ilker Kaya, and Lewell Gunter (2013) used panel data for 46 developing countries, which received foreign aid during the period from 1980 to 2003, to test the relationship between credit for the poor and poverty. They concluded that the direct foreign aid for promoting the agricultural sector, especially in rural areas, was effective in reducing poverty both directly and indirectly. Such evidence can illustrate the vital role of supported aid programs, including direct capital sources and other assistance, for poverty reduction, as further pointed out by Paul Collier and David Dollar (2002). Quach (2005) analyzed the impact of microfinance programs on the welfare of households receiving loans in Vietnam. However, he tested the effect of only formal credit and the impact of loan level on the poor household income.

Bao Duong Pham and Yoichi Izumida (2002) assessed borrowers' perspective through proposing a model to evaluate the determinants of the households' borrowing ability, as well as a model to assess the behavior of formal lenders to satisfy the financial demands of households. They also emphasized the essential role of credit for poor households in the process of rural development, and suggested some indicators that can measure the impacts of loans for poor people. However, they did not measure the influences of each separate indicator on the efficiency of the loans. The process of receiving a loan is complex, as Luigi Guiso, Paola Sapienza, and Luigi Zingales (2004), as and Thorsten Beck (2009) establish. First, a household needs to apply for a loan. However, some households might already anticipate some credit constraints and, therefore, may give up applying, although they need a loan and could use it productively (Gloede and Rungruxsirivorn 2013). Second, lenders have the power to decide whether to grant the loan, and in what amount. Third, households use credit either for consumption or investment. While consumption loans might be needed to afford a living and compensate for income shocks, investment loans could enable a higher income path in the future (Townsend 1995).

Studies, such as the above, have proven the significance of micro-finance in driving the low-income group out of the poverty and then in securing better income. As a developing country, Vietnam is a main receiver of this kind of capital through international programs against poverty and hunger. Our study, on the other hand, focuses on the access to preferential loans, a subject matter that has been rarely analyzed in the literature and then mainly from a program-evaluation point of view (Amin, Rai and Topa 2003; Menkhoff and Rungruxsirivorn, 2011). We use the 2010 Vietnam Household Living Standards Survey to explore influential factors for households' ability to access preferential loans. Through this study, we contribute to a better understanding of the role of access to finance on household welfare. Based on the importance within the process of poverty reduction and socio-economic development, the Law on Bank and Credit Institutions was passed by the Vietnamese Party in 2010, in which microfinance institutions are regarded as financial institutions, codified in provisions and regulations. In December 2011, the Vietnamese government also approved a scheme on building and developing a microfinance system in Vietnam by 2020. Given that there has not been a significant change in the sector over the past four years, the data collected in 2010 are still valid (Vietnam Bank for Social Policy 2012). 


\section{Microfinance in Vietnam}

Vietnam has committed to pursuing the eight MDGs, with a particular focus on poverty reduction and rural development. According to the 2012 World Bank's report, the poverty rate in this country substantially decreased - from 58.1 percent in 1990 to 14.2 percent in 2010 and 9.6 percent in 2011/2012 - demonstrating the outstanding achievements of the Vietnamese government in fighting poverty. In such a context, microfinance programs play a vital role in reaching the target and achieving favorable results. As one of the eleven key principles of microfinance developed by the Consultative Group to Assist the Poor (CGAP 2004), microfinance programs are seen as a powerful instrument against poverty. These programs can be defined as direct credit sources and guidance on how to use the capital most effectively. These programs are also an effective way to reach the poor and improve their lives (ADB 2000). In Vietnam, 68.3 percent of the population lives in the countryside (GSO 2012) and 90 percent of the poor live in rural areas. This suggests that the microfinance programs for poverty reduction in rural areas should play a significant role in this regard.

The main reason for the importance of microfinance in Vietnam is that the poor, who mostly live in rural areas, have no access to capital and lack knowledge regarding how to launch their own business. Thus, they cannot satisfy the requirements of commercial banks to apply for official loans. The terms and requirements of microfinance for access to loans are more straightforward than official loans. Therefore, microfinance is the most effective way for rural populations and poor people to approach loans. In addition, the donor packages in rural finance in Vietnam and the total Official Development Assistance (ODA) for Vietnam over the past two decades have demonstrated the importance of microfinance and preferential loans funded by international organizations for the entire country in general and rural areas in particular in the process of targeting poverty reduction (see Tables 1A and 2A of the Appendices). Deriving from people's demands for microcredit, financial institutions that provide access to microfinance have become very diverse, including the following main groups: Vietnam Bank for Social Policies (VBSP), People's Credit Fund (PCF), microfinance institutions (MFIs), and several commercial banks (i.e., Vietnam Bank for Agriculture and Rural Development - Agribank, Lienviet Post Bank, and Donga Bank). Among them, three institutions - VBSP, PCF, and MFIs - provide credit services to the poor.

[Table 1 about here]

Table 1 indicates that, in 2010, the VBSP provided microcredit for 8.1 million people, of whom 45.7 percent were poor. The outstanding balance of loans for poor people in the same year reached 3,240 million USD. It can be seen that the number of poor clients of the VBSP was higher than the total number of clients having access to microfinance of other institutions. The VBSP plays a key role in the microcredit market. The practical performance of the VBSP shows that preferential financial support programs have substantially contributed to reducing poverty and hunger and ensuring social security. In eleven years of operation, the Social Policy Bank has supported over 23.4 million poor and marginally poor households, improving their economic conditions and enabling their escape from poverty. Microfinance has also assisted around 3.2 million individuals in overcoming the poverty line, has created jobs for approximately 2.7 million workers, and has allowed 100,000 people to go abroad for work, has lent to 3.2 million poor students to continue their education; has funded 4.5 million projects for clean water and sanitation in rural areas, and has built 484,000 houses for poor households (VBSP 2012). The basic mission of the VBSP is to provide low interest and accessible financial services 
to poor residents and rural communities that have been left behind during the steady growth of the Vietnamese economy in recent years. While these objectives are essentially appropriate, the financial services provided by the bank constitute "subsidized credit," which inevitably gives rise to doubts regarding the sustainability of such a system. In addition, the compounding of industrial policy objectives, the integration of risk alleviating measures within the lending program, and the involvement of politics create additional problems. Inevitably, the characteristics of financial services provided by the VBSP are complex by nature (Izumida 2003).

The role of microfinance in creating a chance for the poor to improve their life after being granted a sufficient amount of capital cannot be denied. However, there are studies that document some shortcomings of the lending procedure. This raises the question of how microfinance should be designed to reach its targeted group and minimize efficiency losses. Despite its significance for policy-making, the existing literature offers very limited insight into this question. Preferential loans are a particularly suitable mechanism for improving the development benefits of microfinance programs (Dhakal 2004). Basic criteria are set a priori for these types of loans, and only those that meet these criteria are eligible for funding. In the context of poverty reduction, the criteria are often related to being unemployed, belonging to a low-income household, or being economically disadvantaged. Clearly, individuals and households that satisfy these criteria, although they form a sizeable proportion of the population in developing countries, are excluded from funding by conventional credit institutions like banks, in which collaterals and formal employment are often required to access funds. In this light, preferential loans offer an opportunity for inclusive development by offering the means of improved livelihood to otherwise marginalized segments of the population.

\section{Objectives}

We examine the impact of preferential loans on household income in the context of Vietnam. We approach the probability that Vietnamese households have access to preferential loans and the relationship between preferential loans and the household income - with the hypothesis that households with access to these loans should have improved income on average. An additional aspect that we consider is the rural-urban difference in income. We examine whether the geographical disparity persists in the presence of preferential loans and whether it actually impacts the significance of the loans as a poverty reduction mechanism.

In the next section of the article, we present our methodology, including the survey design, the data, and the regression model. Given that income can potentially improve the living standards and even help get rid of poverty, our regression model examines the role of preferential loans on household income as the main determinant of the welfare of households. We present out results and discussion in the third and fourth section respectively, and draw some conclusions in the final section.

\section{Data Set}

\section{Methodology}

\section{Survey Design}

We use a data set from the Vietnam Household Living Standard Survey (VHLSS) of 2010. The VHLSS is a biennial survey conducted nationwide by the General Statistics Office (GSO) of Vietnam, with the World Bank's support. The aim is to collect information in order to capture 
the household living standards and poverty status in Vietnam. We make the assumption that the results derived from the survey support social and economic development policies.

The VHLSS surveys are conducted at the household level and on the basis of many factors, including demography, employment, education, health, expenditure, housing, and microfinance. The surveys are also representative at national, regional, urban, rural, and provincial levels across Vietnam. Because the master sample of VHLSS by 2008 was deemed outdated, the GSO proposed an updated method of implementing the new master sample in 2009. This master sample is a 15-percent subset, drawn from the Population and Housing Census of 2009 by using a systematic random sampling. Figure 1 shows the steps of selecting the master sample.

[Figure 1 about here]

\section{Description of Variables}

Using direct surveys, a surveyor visited each household and posed questions to the household members. In addition, to avoid the differences between surveyors, two survey questionnaires - namely, the household level questionnaire and the commune level one were used, which are designed to gauge detailed information. Table 2 presents an overview of the variables we use in this study.

[Table 2 about here]

\section{Models}

As we already discussed, our main purpose is to assess the probability of households getting access to preferential loans for stimulating their production activities and the impact of loans on household income. This is one of three poverty-reduction indicators issued by the Vietnamese government: namely, (i) decreasing the number of poor households in the country, (ii) improving household income, and (iii) increasing the possibility of accessing social security and social benefits. This is in accordance with the Vietnamese Prime Minister's Decision No. 20/QD-TTg to codify the National Target Program on Poverty Reduction in the period FROM 2006 to 2010. Thus, our main hypothesis are as follows:

H1: Individual characteristics have a marginal effect on the access to preferential loans.

H2: Household characteristics are influential factors on the access to preferential loans.

H3: Households having access to preferential loans have improved income.

$\mathrm{H} 4$ : Most of the preferential loans target rural population.

We classify factors that may have an impact on the access to these loans and on the income of households into three groups:

- Individual characteristics, including age and Kinh ethnicity;

- Household characteristics, including household laborers, education level, income, the total value of asset, and debt;

- Regional characteristics, including the area where the household is located (urban or rural). 
In order to reach a deeper understanding of the probability of accessing preferential loans, as well as assess the impact of these loans on household income, we apply two regression models. In the first regression, we model the probability of a household's receiving preferential loans, as shown in equation (1):

$$
P(X)=\beta_{0}+\beta_{i} X_{i}+\varepsilon_{i}
$$

$P(X)$ is the probability of households getting the loans. $P(X)$ can have values of 0 and 1 for households with non-borrowing debt and borrowing debt, respectively. $X_{i}$ indicates a set of vectors that includes: (1) individual characteristics of age and Kinh ethnicity; (2) characteristics of the household head's educational status, household laborers, and the household's total asset value; and (3) regional characteristics (urban or rural; developed and less developed regions). $\varepsilon_{i}$ is the residual that follows a normal distribution and captures the effects of unobserved variables.

In the second regression model, after scanning the data, we observed the existence of outliers, the difference between median value and mean value (as Table $3 \mathrm{~A}$ shows), which will affect the regression results. In order to eliminate some backward deviation of the linear regression model, we apply the quantile regression model - as presented in equation (2) - with the purpose to find the determinants of household income, in association with preferential loans at different quantile levels. Additionally, we classify all the independent variables into three categories: (i) individual, (ii) household, and (iii) regional characteristics. Compared to previous studies, which only list all variables and then directly apply them to the models, our dividing the independent variables into three groups facilitates the consideration of most factors affecting poverty reduction that is directly reflected by household income.

$$
f(Y)=\alpha_{0}^{(p)}+\alpha_{1} \chi_{1}^{(p)}+\alpha_{i} X_{i}^{(p)}+u_{i}^{(p)}
$$

In equation (2), $F(Y)$ is the magnitude of household income that is calculated based on the production activities in a given year (in our case, 2010). $X_{1}$ is the dummy variable with values of 1 and 0 for borrowing and non-borrowing households, respectively. $\chi_{i}$ stands for a set of explanatory variables, including the age of household heads, the number of household laborers, the educational status of the household head, the area where households are located (urban and rural), the household region, Kinh ethnicity, and the total asset value. For any $p C(0,1)$, the $p$-th quantile of $Y$ is defined as $Q(p)=\inf \{Y: f(Y) \geq p\}$. $p$ indicates the percentage of households having income below the quantiles $p$. By exploring the quantile regression, we model the relationship between all the covariates and the dependent variable at differently possible $p$ (quantiles). It specifies changes at different levels of the quantiles of the explained variable.

Generally speaking, in linear regression, a one-unit increase in the regressor coefficient leads to an increase or decrease in the response variable, whereas the quantile regression parameter measures the change in a specified quantile of the dependent variable. This enables us to observe how a specified percentile of household income may be more affected by certain characteristics of individuals, households, and regions than other percentiles. In sum, while Equation (1) highlights the importance of socio-demographic variables in explaining the likelihood of a household's accessing loans, Equation (2) estimates the differences in average earnings between households that accessed preferential loans and those that did not at different quantile levels. 


\section{Results}

\section{Profiles of Borrowing and Non-Borrowing Households}

In order to comprehensively examine typical characteristics of the borrowing and nonborrowing household groups, we examine the general profile of these households through explanatory variables shown in Table 3. Overall, there is a significant difference in the number of observations between these two groups. While we count 1,260 borrowing households in the sample data, there are 8,142 observations for non-borrowing households. Statistically, the average income of non-borrowing households is estimated at 71.6 million VND (3,582 USD), whereas that of borrowing households is 42 million VND (2,101 USD). Two main reasons account for this disparity: (i) the larger range of the data sample, where the number of nonborrowing households is 6.5 times higher than borrowing households (this can make the income range wider); and (ii) the number of non-borrowing households living in urban areas. Technically speaking, of the 8,142 non-borrowing households, 2,453 (or 30 percent) live in urban areas. It is one of the main factors leading to an increase in the household income regardless of access to preferential loans. We also present the impact of the area on household income in the regression models. In addition, the members of households that borrowed preferentially are 45 years old on average, which is four years younger than the members of non-borrowing households. This suggests that younger families have more possibilities of accessing loans for their business than older ones.

[Table 3 about here]

Table 4 presents the correlation matrix among all the variables we use for the regression model. As Table 4 shows, there is a positive correlation between some variables (including labor, education, region, Kinh ethnicity, and total asset value) and the magnitude of income. However, there is a negative correlation between the level of income and the rest of the variables - namely, household debt and household location. We define debt as the amount that households borrowed through preferential loans. Additionally, the number-of-household laborers and rural-area variables have a positive correlation with the household access to loans, with a 99-percent confidence level. On the other hand, there is a negative correlation between access to loans and a range of variables like age of household head, educational status, region, Kinh ethnicity, and total asset value. The correlation coefficients among all variables are significant, with a confidence level of 95 and 99 percent. Moreover, we use this matrix to test the probability of getting multi-collinearity among variables in the models. As Table 4 shows, most correlation coefficients between pairs of variables are small and their absolute values are all below 0.8 . This indicates that the probability of getting multi-collinearity in the regression model is considerably low.

\section{[Table 4 about here]}

In order to find out whether there are any linkages between income level and access to loans, we perform a T-test between the two groups. As Table 5 shows, the borrowing group had a lower average income of 29,605,000 VND (approximately 1,500 USD) as compared to nonborrowers. This finding could stem from the location of the households. Table 6 indicates that most $(84 \%)$ of the households with access to preferential loans are from rural areas. In fact, the number of rural households that borrowed preferentially is twice higher than borrowing urban 
households. These figures generally suggest that the demand for microfinance, particularly of the preferential type, may be greater in the relatively poor rural areas.

\section{[Table 5 about here] \\ [Table 6 about here]}

To test whether there is a significant linkage between the level of household income and the location of a household, we apply a T-test to check the hypothesis that households living in urban areas have higher average income than those living in rural areas. As Table 7 indicates, this hypothesis can be accepted with a 95-percent confidence level. It can be seen that, despite the overwhelming number of rural households, the average income of those living in rural areas is 13,832,000 VND (approximately 692 USD) lower than that of urban households. In general, access to credit would partly improve the income of the poor, and once they decide to take loans, factors like age and household location would substantially affect their ability to earn higher income. Our results from the multivariate analysis demonstrate this relationship in the section that follows.

[Table 7 about here]

\section{Empirical Results}

As previously stated, the first stage of our regression model examines the probability of households getting access to preferential loans. Table 8 contains the result of the first regression. In this regression model, all the observed explanatory variables (except the variable of education) show a significant correlation with a household's ability to access preferential loans. Among them, the location (urban or rural) and the number-of-household-laborers variables have a positive relationship with the dependent variable. As Table 8 indicates, a oneunit increase in the household labor capabilities raises the probability of households accessing loans by 2-percent, with 99-percent confidence level. This result can be explained by the fact that Vietnamese households mainly carry out their production activities by internal laborer source. Consequently, a household will more likely have a larger scale of production activities that could create a higher need for capital. Similarly, living in rural or urban areas has a positive impact on households' access to loans in Vietnam. With a 95-percent confidence level, our result show that those who reside in rural areas are more likely to get access to loans than urban residents.

\section{[Table 8 about here]}

By contrast, the age of household heads, region, Kinh ethnicity, and total asset value demonstrate a negative relationship with the probability of households' accessing preferential loans. As Table 8 shows, a one-unit increase in the age of a household head decreases the probability of a household's borrowing by 0.17 percent. It means that the older the household head is, the less probable it is that he/she would access loans. Likewise, being from the more developed regions, including the Red River Delta and the Southeast of Vietnam (World Bank 2012) reduces the likelihood of having access to preferential loans by 4.92 percent, when compared to being from the less developed regions - namely, East Northern Mountains, West Northern Mountains, North Central Coast, South Central Coast, Central Highlands, and 
Mekong Delta. This result overlaps with the Vietnamese government's policies to provide preferential loans to groups residing in underdeveloped areas.

With a 99-percent confidence level, there is a negative correlation between the variable of Kinh ethnicity and the probability of borrowing preferentially. In other words, the Kinh in Vietnam, who accounts for 86 percent of the total population, are less likely to access loans as compared to all ethnic minorities combined, which constitute 11.12 percent of the total population. Additionally, a one-million VND (approximately 45 USD) growth in total asset value reduces the possibility of households' preferential borrowing by 9.79 percent. This means that the more assets a household possesses, the less likely it is to have access to preferential loans.

Table 9 presents our quantile regression results, indicating the impact of the regressors' values on the dependent variable in terms of percentage changes. As Table 9 indicates, with a 99-percent confidence level, all explanatory variables have a significant effect on household income. By exploring the quantile regression, a more comprehensive picture of the impact of the predictors on the response variable comes to light in Table 9. Accordingly, a set of explanatory variables - debt, the age of a household head, and the household location (urban or rural) - has a negative correlation with household income. In the linear regression model, the average income of those who borrowed preferentially is 21.73 percent, which is calculated by $e^{-0.2450}-1$, lower than that of non-borrowing households. However, our results show that at the lower quantiles of household income, the debt factor has deeper impact on the borrowing group. On average, the 25th and 50th income level of borrowing households are 12.6 and 19.5 percent, respectively, lower than that of non-borrowing households.

[Table 9 about here]

The impact at the 25th and 50th quantiles are underestimated by our linear regression. This fact can be explained by three main reasons. First, based on the descriptive statistics in Table 3, we find that the mean income of borrowing households was 42,037 VND $(2,101$ USD) in the given year (2010), which is 1.7 times lower than that of the non-borrowing ones. For this fact, the non-borrowing households themselves have higher level of income compared to the borrowing ones. Second, the number of non-borrowing households reached 8,142, while that of the borrowing ones was merely 1,260. This 6.5-time disparity shows a wide range in the data sample that makes the income range bigger. This makes it hard for non-borrowing households to catch up with their counterpart in terms of income level. Third, several studies (e.g., Diagne and Zeller 2001) proved that micro-credit programs in general and preferential loans in particular are not always effective in improving income for all households, or in alleviating poverty. Accordingly, such studies do not find a statistically significant relationship between micro-credit packages and household income in Malawi. Yet, after all, the coefficient of debt in Table 9 can only indicate the short-term negative impacts of preferential loans on household income.

Furthermore, the negative coefficients of age and household-income valuables show a general tendency toward lower income, the older the household head is. Specifically, a downward tendency of this predicted variable in higher quantiles indicates that the effect of age has a larger negative impact on the lower quantiles of the income level. At the 50th quantile level, a one-unit increase of age on average decreases the household income by 2.0 percent.

Additionally, among other independent variables, rural residency variable has the biggest negative effect on income as the absolute value of its coefficient is greater than the other 
negative-coefficient variables. With a 99-percent confidence level, this negative coefficient illustrates that the income magnitude of those living in rural areas is lower than that of urban residents. At the 25th quantile of income level, the income of rural households is, on average, 19.86 percent lower than that of urban households. Meanwhile, the difference between rural and urban household incomes can be averaged at 24.87 and 24.35 percent at the 50th and 75th quantiles of income level, respectively. These results indicate that living in urban areas definitely gives people an advantage in securing higher income, thus urbanization has been presumed as one of the instruments for poverty reduction and rural development (Nguyen 2012). Chi Loi Cu (2005) similarly states that industrialization usually takes place in urban areas with the expansion of existing enterprises, which partly improves the livelihoods of people by increasing their personal income. These arguments support our finding that average income at the 25th quantile level of urban households is 19.86 percent higher than that of rural households. It is also consistent with Elena Saraceno's (1994) finding that the rural-urban traditional migration patterns have been considerably reversed in the last twenty years.

On the other hand, such variables as number of household laborers, educational status of household heads, Kinh ethnicity, and total asset value have a positive relationship with the level of household income. As Table 9 shows, the number of household laborers in the lower quantiles has a more significant impact on the earning capacity of an entire family. At the 25th quantile of income, we find that a one-unit increase in the number of household laborers increases household income by 39.4 percent on average. Meanwhile, at the higher income quantiles of 50 and 75 percent, increasing the number of laborers in the household by one leads to an average income growth of 33.4 and 29.6 percent, respectively. This positive influence can be predicted because the business activities of households in Vietnam mainly depend on the labor capacity of family members.

Similarly, the education variable also displays an upward tendency in lower quantiles. This particular explanatory variable receives the largest absolute value among the remaining variables. Our regression result demonstrates that the effect of the household head's education level has a larger positive impact on the lower quantiles of the income level. The 25th quantile of income for households with a well-educated head is 96 percent higher, on average, than households with less educated head of family. In our linear regression, this value is 76.4 percent on average. This shows the substantial impact of educational attainment on improving household income, especially for the low-income group.

The predicted variables of Kinh ethnicity and total asset value show a similar tendency of upward trend in higher quantiles of income level. At the 50th quantile level, people belonging to the Kinh ethnicity, which is the largest ethnic group in Vietnam, have a 51.4-percent higher income, on average, than those belonging to other ethnic groups. Meanwhile, the difference of income between the Kinh people and ethnic minorities stands at 45.3 percent on average. As Table 9 shows, we also find that a big gap in the impact of total asset value on household income at each quantile level, a gap that is particularly pronounced between the 25th and 75th quantiles of income. Accordingly, an increase of one million VND (50 USD) of the total asset value that households possess results in an income growth of 13.5 and 68.2 percent at the 25th and 75th quantile levels, respectively. This fact indicates the significant contribution of household assets to generating higher income among Vietnamese households.

Overall, the two models we propose explain several variables that influence the probability of households' access to preferential loans and the factors that determine income level linked to such loans. Of those variables, we test the short-term impact of preferential loans in association with borrowing households' income, compared to the level of income of nonborrowing households. Albeit the $\mathrm{R}^{2}$ value for the quantile regression results is about 9-to-12 
percent, the low value can be explained by the fact that income is a sensitive variable which is influenced by a wide range of variables beyond those included in our analyses. For instance, the quantity and quality of production as well as the amount of loans are important, but unavailable in our dataset.

\section{Discussion}

From statistical analyses, we determine several important factors that influence the access to preferential loans. Moreover, we analyze the determinants of household income level in relationship to preferential loans by exploring a quantile regression model. Furthermore, we carefully examine the role of preferential loans as a component of micro-credit from a number of previous studies. For example, M.H. Quach (2005) shows that rural households in Vietnam are more likely to get access to formal financial sector loans. Quach's study, however, suffers from a serious limitation, as it only measures the impact of access to loans on poverty reduction of households in rural areas. By contrast, our research is conducted at national level, using data from both rural and urban areas. Accordingly, by applying the quantile regression model, we found that "urban: residency, education level, ethnicity, and number of household laborers are important explanatory factors for improving household income. Our findings also concur with Viet Cuong Nguyen's (2012) stipulation that urbanization can be a crucial factor in increasing the income and reducing the poverty of rural households in Vietnam. His research further shows that a 1.0-percent increase in urbanization helps decrease rural household poverty by 0.17 percent.

Furthermore, Quach's (2005) study merely tests the probability of loan-participant households, the determinants of changes in the amount borrowed for participant households, and the impact of revolved loans on household wellbeing. Meanwhile, we test both the factors influencing the access to loans and the difference in the short-term impact of these loans on different income groups through the quantile regression method. We are inclined to conclude that micro-credit is not always effective in improving the income of all households (Diagne and Zeller 2001), especially in the short term. Simultaneously, we concur with Cuong Nguyen et al. (2007, 11) that "a finance-program should lead to capital accumulation and financial deepening, but these effects will take at least ten years to materialize."

In addition to several important, independent variables - such as age, education, and household laborers that Quach (2005) uses - we added some other variables into our regression model: debt, area, region, ethnicity, and total asset value. These added variables proved to play significant roles in our examination of the household income's determinants. Our findings are in line with T.T.H. Nguyen's (2011) analysis of the coexistence and cooperation of different financial sectors (formal, semi-formal, and informal sectors) in the Phu Thuong Commune (Thua Thien Hue Province) in Vietnam. Nevertheless, Nguyen's (2011) study does not examine the household characteristics, which considerably affect both the households' income and their borrowing behavior. Our study is more comprehensive by using nationwide figures, and it also examines some important individual, household, and regional characteristics. Nara Hari Dhakal $(2004,13)$ demonstrates that access to financial services has substantial influence on both economic and social aspects, including "increased income, improved nutrition, better food intake, better consumption on clothing, better housing, lower child mortality, lower birth rate, higher adoption of family planning practices, better health care, better access to education for children, empowerment of women, participation in social and political activities, etc." In our study, we further examine how to get access to preferential 
loans by running a probit regression model to analyze some crucial factors that have an impact on the probability of household access to loans.

\section{Conclusions}

In our regression model, we examine the impact of preferential loans on household income as the main determinant of the welfare of households. Oliver Gloede and Ornsiri Rungruxsirivorn (2013) study the relationship between financial development and welfare focusing on three dimensions of household welfare: vulnerability to poverty, investment, and consumption smoothing. Our results suggest that access to preferential loans improved household income. In the line with our study, Thorsten Beck (2009) reviews the relationship between financial development and growth. He illustrates that financial development enhances growth and welfare. Luigi Guiso, Paola Sapienza, and Luigi Zingales (2014) similarly suggest that local financial development is an important determinant of the economic success of an area, even in an environment where there are no frictions to capital movements. Our results also suggest that microcredit is not effective in reaching poor people living in rural areas. Likewise, Lukas Menkhoff and Ornsiri Rungruxsirivorn's study (2011) shows that village funds provide services to lower income households better than formal financial institutions. Sajeda Amin, Ashok Rai, and Giorgio Topa (2003) evaluate whether microcredit programs reach the relatively poor and vulnerable in two Bangladeshi villages, and they find that, while microcredit is successful at reaching the poor, it is less successful at reaching the vulnerable.

Regarded as a key target country by international organizations, Vietnam has been aided by many sponsored programs and projects with a large amount of capital to battle against poverty. Thanks to this support, the nation has recorded a number of outstanding successes that were highly praised by the international community (World Bank 2012). During the longterm process of achieving such successes, it cannot be denied that preferential loans have played a vital role in providing the poor with sufficient capital to run their businesses. We draw several conclusions from our effort to measure the probability of households' access to preferential loans and the determinants of household income associated with access to such loans in Vietnam.

Conclusion 1: Ethnicity-related factors have the largest average marginal effect on the access of households to preferential loans. From the quantitative results of our study, we note that the probability of ethnic minority households in accessing preferential loans is 11.12 percent lower than for the Kinh people, who are the dominant ethnic group in Vietnam. This finding is fully consistent with Hai-Ahn Dang's (2012) analysis that minority groups in Vietnam have less access to financial services. Although ethnic minorities account for less than 20 percent of the total Vietnamese population, they constitute more than half of the poor in the country (Pham, Dang and Nguyen 2010). Therefore, the Vietnamese government should consider a policy measure meant to enhance the access of minority groups to preferential loans.

Conclusion 2: The educational status of household heads is a significantly influential factor among low income households. Equipped with better knowledge, heads of households may be better positioned to improve the productivity of their households, particularly in controlling costs and deciding which plants/animals would better serve their households' businesses. By applying the quantile regression model, we found that at the lowest quantile of income, households with better educated household heads have a 96-percent higher income, on average, than their counterparts. This rate is gradually decreasing in the higher quantiles of income level. Accordingly, our study raises the question: Should the Vietnamese government thoroughly reconsider its educational programs to gear them toward the poor in light of the 
revelation that education leads to poverty reduction and improved household income? We recommend that the Vietnamese government prioritizes programs of poverty reduction, with a specific focus on education and development in rural areas. We further suggest that programs be designed to provide the poor with sufficient knowledge to effectively operate a business.

Conclusion 3: In terms of short-term impact, preferential loans do not appear to substantially improve the income of borrowing household as compared to non-borrowing ones. Our quantile regression results indicate that, at the lower quantile levels, there is a progressive reduction of the negative impact of preferential loans on the income of non-borrowing households. These results can be considered as a lower benchmark of the impact of preferential loans on improving household income because we only measure this impact in the short term due to limited data availability. Meanwhile, the effects of financial programs on socio-economic targets might take no less than a decade to materialize. In addition to providing the poor or low-income households with capital, it is essential that preferential financial-service suppliers provide specific guidance for (the mostly poor and minority) borrowers on how to utilize preferential loans most effectively.

Furthermore, our study introduces a quantile-regression model to provide a comprehensive picture of the effects of variables, particularly access to loans, on household income at different quantile levels. This econometric model figures out the different impacts of the determinants at the different quantiles of income. This can be regarded as an important contribution to literature by virtue of our testing the impact of the determinants on household income at the different levels of data distribution. Accordingly, we examined existing findings regarding the lowest quantile level - i.e., the 25 percent of the lowest income households.

The link between preferential loans and income is of a dynamic nature. Besides improving income, investment loans could lead to higher income paths for households if used effectively. Due to the restriction of data availability, we could not test the long-term impact of preferential loans on household income. In future studies, if data for more than one year are available, researchers can explore the panel data regression to examine whether preferential loans can help the poor become better off in the longer run. In addition, future research can test how households' debt history affects preferential loans and their impact on income - that is, how a household who had failed to repay a loan could receive another one. Moreover, by categorizing borrowing channels, then testing the different level of effect on the income level of each channel, future researchers can test the role of formal and informal credit systems in contributing to poverty reduction. We mainly focused on examining the impact of preferential loans on household income. Preferential loans could restructure existing loans to reduce the debt burden of households, and other debts could also pose a limit to the total take-up of preferential loans. We recommend that future studies focus on determining the impact of other loans on access to preferential loans and income. Another implication to be considered in future studies is the role of social capital in the struggle for poverty alleviation. Social capital is a resource used to tackle socio-economic issues, as well as to improve living standards and human wellbeing (Besser 2009). The lack of relevant data did not allow us to directly assess the role of social capital, which would have made it possible to present a more comprehensive picture on the long-term impact of preferential loans on household income and poverty reduction. 


\section{References}

Amin, Sajeda, Ashok Rai and Giorgio Topa. "Does Micro Credit Reach the Poor and Vulnerable? Evidence from Northern Bangladesh.” Journal of Development Economics 70, 1 (2003): 59-82.

Asia Development Bank (ADB). "Finance for the Poor: Microfinance Development Strategy." Manila, Philippines: ADB, 2000.

Beck, Thorsten. "The Econometrics of Finance and Growth." In of Palgrave Handbook of Econometrics: Applied Econometrics, Vol. 2, edited by Terence S. Mills and Kerry Patterson, pp. 1180-1212. Basingstoke, UK: Palgrave Macmillan, 2009.

Besser, Terry L. "Changes in Small Town Social Capital and Civic Engagement." Journal of Rural Studies 25, 2 (2009): 185-193.

Collier, Paul and David Dollar. "Aid Allocation and Poverty Reduction." European Economic Review 46, 8 (2002): 1475-1500.

Consultative Group to Assist the Poor (CGAP). "Key Principles of Microfinance." Washington, D.C.: CGAP, 2004.

Craig, David and Doug Porter. "Poverty Reduction Strategy Papers: A New Convergence." World Development 31, 1 (2003): 53-69.

$\mathrm{Cu}$, Chi Loi. "Rural to Urban Migration in Vietnam." In Impact of Socio-economic Changes on the Livelihoods of People Living in Poverty in Vietnam, edited by Ha Huy Thanh and Shozo Sakata, ch. 5. Institute of Developing Economies, Japan External Trade Organization, 2005.

Dang, Hai-Ahn. "Vietnam: A Widening Poverty Gap for Ethnic Minorities." Indigenous People - Poverty and Development Report. New York, NY: World Bank, April 15, 2012.

Dhakal, Nara Hari. "Microfinance for Achieving Millennium Development Goals in Nepal." Agricultural Credit - A Bi-annual. Journal of ADB/N 37 (2004): 1-18.

Diagne, Aliou and Manfred Zeller. "Access to Credit and Its Impact on Welfare in Malawi." Research Report No. 116. Washington D.C.: IFPRI, 2001.

Driscoll, Ruth and Alison Evans. "Second-Generation Poverty Reduction Strategies: New Opportunities and Emerging Issues." Development Policy Review 23, 1 (2005): 5-25.

Gloede, Oliver and Ornsiri Rungruxsirivorn. "Local Financial Development and Household Welfare: Microevidence from Thai Households." Emerging Markets Finance and Trade 49, 4 (2013): 22-45.

Guiso, Luigi, Paola Sapienza and Luigi Zingales. "Does Local Financial Development Matter?" Quarterly Journal of Economics 119, 3 (2004): 929-969.

Hamilton, David. "Reciprocity, Productivity and Poverty." Journal of Economic Issues 4, 1 (1970): $35-42$.

Izumida, Yoichi. "Vietnam 1RKVRQ. LQQ $\backslash X$ QR 6KLQ WHQNDL (Evolution of Rural Finance in Vietnam)". Department of Agricultural and Resource Economics Working Paper Series. No 3. F-01 (2003). University of Tokyo. International fund for agricultural development socialist republic of Vietnam. "Review on investment options for ifad in rural finance sector." 2012.

Kaya, Ozgur, Ilker Kaya and Lewell Gunter. "Foreign Aid and the Quest for Poverty Reduction: Is Aid to Agriculture Effective." Journal of Agricultural Economics 64, 3 (2013): 583-596.

Menkhoff, Lukas and Ornsiri Rungruxsirivorn. "Do Village Funds Improve Access to Finance? Evidence from Thailand.” World Development 39, 1 (2011): 110-122. 
Nguyen, K.A., T.V. Ngo, T.T. Le and T.T.M. Nguyen. "Tài chính vi mô với giảm nghèo ở Việt Nam: Kiểm định và so sánh." ["Microfinance for Poverty Reduction in Vietnam: Inspection and Comparison].” Vietnam: Statistical Publishing House, 2011.

Nguyen, Cuong, David Bigman, Marrit Van den Berg and Thieu. Vu. "Impact of Micro-Credit on Poverty and Inequality: The Case of the Vietnam Bank for Social Policies." MPRA Paper No. 54154. Munich, Germany: University Library of Munich, 2007.

Nguyen, T.T.H. "Credit Market Segmentation in Rural Areas: A Case Study in Phu Thuong Commune, Phu Vang District, Thua Thien Hue Province.” Uppsala, Sweden, 2011.

Nguyen, Viet Cuong "Does Urbanization Help Poverty Reduction in Rural Areas? Evidence from a Developing Country." MPRA Paper No. 48660. Munic, Germany: University Library of Munich, 2012.

Pham, Bao Duong and Yoichi Izumida. "Rural Development Finance in Vietnam: A Microeconometric Analysis of Household Surveys." World Development 30, 2 (2002): 319 335.

Pham, T.H., L.T. Dang and V.C. Nguyen. "Poverty of the Ethnic Minorities in Vietnam: Situation and Challenges from the Poorest Communes." MPRA Paper No. 50372. Munich, Germany: University Library of Munich, 2010.

Quach, Manh Hao "Access to Finance and Poverty Reduction: An Application to Rural Vietnam.” Ph.D. diss., University of Birmingham, 2005.

Saraceno, Elena. "Recent Trends in Rural Development and Their Conceptualization." Journal of Rural Studies 10, 4 (1994): 321-330.

Swartz, Caroline."The Rational Peasant: The Political Economy of Rural Society in Vietnam.” Journal of Economic Issues 15, 1 (1998): 277-280.

Townsend, Robert M. "Consumption Insurance: An Evaluation of Risk-Bearing Systems in Low-Income Economies.” Journal of Economic Perspectives 9, (1995): 83-102.

UNDP. "Human Development Report." UN, 2014. Available at http://hdr.undp.org/en/content/human-development-report-2014. Accessed November 3, 2017.

Vietnam Bank for Social Policy (VBSP). "Báo cáo thường niên 2012.” Annual Report. Hanoi, Vietnam: VBSP, 2012.

Weiss, John. "The Aid Paradigm for Poverty Reduction: Does It Make Sense?" Development Policy Review 26, 4 (2008): 407-426.

Winter, Gérard. "L'impatience des pauvres.": Presses Universitaires de France, 2002.

World Bank. "Reviewing Poverty Reduction Strategy Program." World Bank, 2001. Available at

http://documents.worldbank.org/curated/en/156931468138883186/pdf/298000018213 1497813.pdf

World Bank. "Well Begun, Not Yet Done: Vietnam's Remarkable Progress on Poverty Reduction and the Emerging Challenges." Hanoi, Vietnam: World Bank, 2012. Available at

http://documents.worldbank.org/curated/en/898561468322131999/pdf/905940PUB09 78100Box385314B00PUBLIC0.pdf.

Yunus, Muhammad "Expanding Microcredit to Reach the Millennium Development Goal, Grameen Bank, Bangladesh.” Paper presented at the International Seminar on Attacking Poverty with Microcredit, organized by PKSF in Dhaka, Bangladesh, January 8-9, 2003. 


\section{Figure and Table}

Figure 1. Master Sample Method for Vietnam Household Living Standard Survey in 2010 (VHLSS 2010)

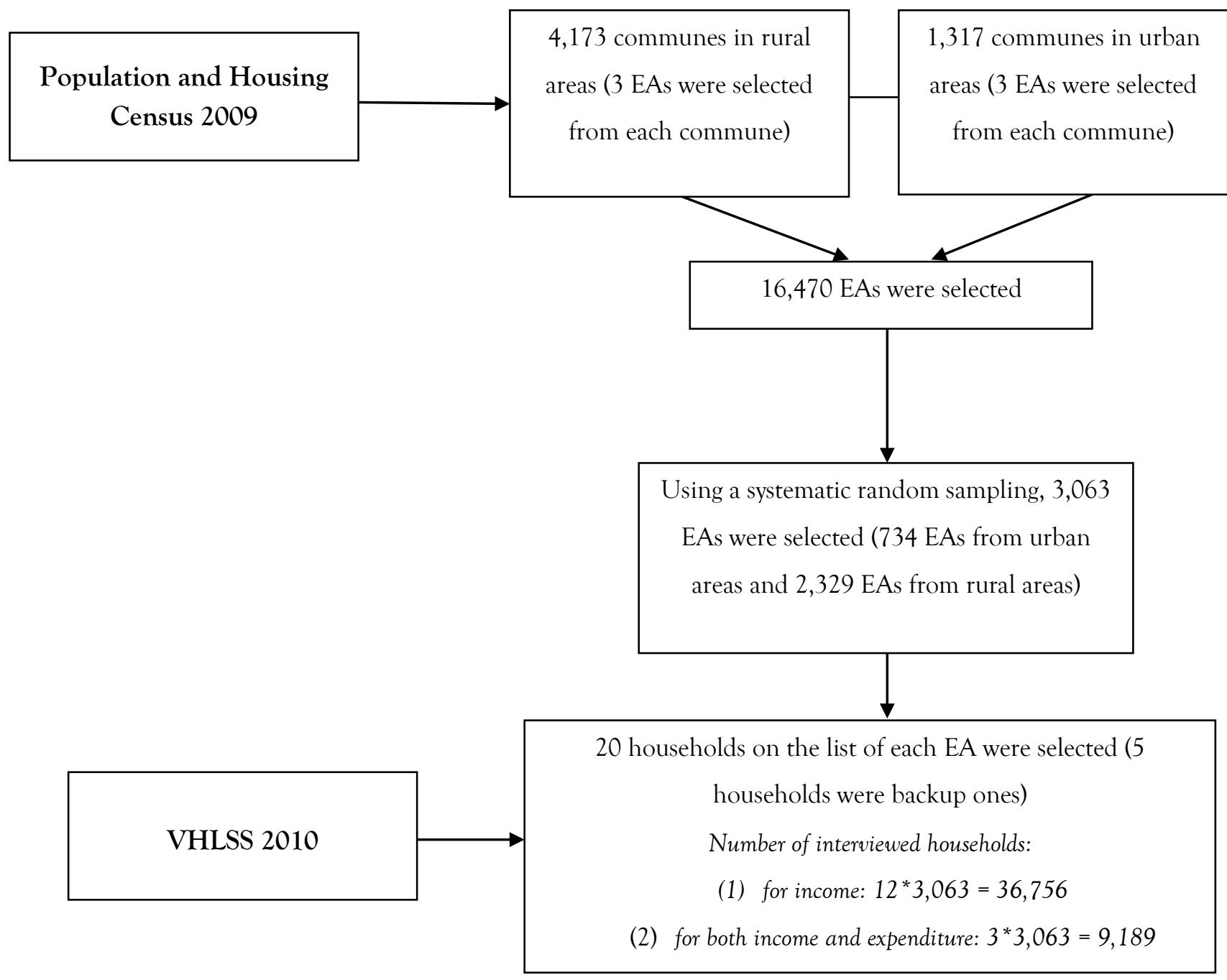

Notes: The survey is designed to collect information in order to capture the household living standards and poverty status in Vietnam. EAs stands for enumeration areas.

Table 1. Profile of Micro-Credit Delivery in Vietnam in 2010

\begin{tabular}{c|c|c|c|c}
\hline \hline Institutions & $\begin{array}{c}\text { Number of } \\
\text { borrowers (million) }\end{array}$ & $\begin{array}{c}\text { Percent of total } \\
\text { borrowers }\end{array}$ & $\begin{array}{c}\text { Outstanding loans } \\
\text { (million USD) }\end{array}$ & $\begin{array}{c}\text { Percent of total } \\
\text { outstanding loans }\end{array}$ \\
\hline $\begin{array}{c}\text { VBSP: } \\
\begin{array}{c}\text { Preferential loans } \\
\text { for the poor }\end{array}\end{array}$ & 8.1 & 59.6 & $\begin{array}{l}4,588.0 \\
3,240.0\end{array}$ & 46.5 \\
\hline Agribank & 3.7 & 23.5 & $3,500.0$ & 35.5 \\
\hline PCF & 3.2 & 12.5 & $1,700.0$ & 17.2 \\
\hline MFIs & 1.7 & 4.4 & 75.0 & 0.8 \\
\hline \hline
\end{tabular}

Source: Nguyen et al. (2011). Notes: The dataset was collected from the 2010 Annual Report by Vietnam's Bank for Social Policies (VBSP), the 2010 Report by Agribank, the 2010 Annual Report of the People's Credit Fund (PCF), and the 2010 Report of Microfinance Institutions (MFIs) provided by the Vietnam Microfinance Working Group. 
Table 2. Survey Variables

\begin{tabular}{|c|c|}
\hline Variables & Description \\
\hline \multicolumn{2}{|r|}{ Individual characteristics } \\
\hline Age & Age of the household head in each household. \\
\hline Kinh & $\begin{array}{l}\text { Dummy variable of } 1 \text { for Kinh and } 0 \text { for others. } \\
\text { Kinh is the most prevalent ethnicity in Vietnam, which accounts for } 86 \text { percent of total population. }\end{array}$ \\
\hline Education & Dummy variable of 1 and 0 for qualifications and non-qualifications, respectively. \\
\hline \multicolumn{2}{|r|}{ Household characteristics } \\
\hline Laborer & The number of household laborers. \\
\hline Income & $\begin{array}{l}\text { Income from production activities, which is profits from crop production, husbandry, agricultural } \\
\text { services, forestry, aquaculture production and exploitation, etc. Income is measured in Vietnam Dong } \\
\text { (VND). }\end{array}$ \\
\hline Assets & $\begin{array}{l}\text { Total asset value includes values of all durables that the households have in a given year (2010). } \\
\text { Total asset value is measured in VND. }\end{array}$ \\
\hline Debt & $\begin{array}{l}\text { Dummy variable of } 1 \text { for borrowing households and } 0 \text { for non-borrowing ones. The preferential } \\
\text { loans, which households borrowed, are provided by the Vietnam Bank for Social Policies, the } \\
\text { Employment Support Fund, the Poverty Reduction Fund, and the Socio-political Organizations. } \\
\text { (The provision of preferential loans we use here derives from the classification of the VHLSS 2010, } \\
\text { shown in the questionnaires.) }\end{array}$ \\
\hline \multicolumn{2}{|r|}{ Regional characteristics } \\
\hline Rural & Dummy variable of 1 for rural and 0 for urban. \\
\hline Region & $\begin{array}{l}\text { Dummy variable of } 1 \text { for developed regions in Vietnam, which are Red River Delta and Southeast; } \\
0 \text { for the less developed ones, including East Northern Mountains, West Northern Mountains, } \\
\text { North Central Coast, South Central Coast, Central Highlands, and Mekong Delta. }\end{array}$ \\
\hline
\end{tabular}

Notes: The variables we use are from the 2010 VHLSS questionnaires. We selected the variables that are directly related to the assessment of household income. The individual characteristics of households are represented by the household head's characteristics.

Table 3. Descriptive Statistics of Variables

\begin{tabular}{|c|c|c|c|c|c|c|}
\hline & Variables & Obs. & Mean & Std. dev. & Min. & Max. \\
\hline & $(1)$ & $(2)$ & (3) & (4) & (5) & $(6)$ \\
\hline & Borrowing households & 1,260 & 42,037 & 85,389 & 0 & $1,778,615$ \\
\hline Income & Non-borrowing households & 8,142 & 71,642 & 283,501 & 0 & $1.68 E+07$ \\
\hline$A_{\gamma}$ & Borrowing households & 1,260 & 45 & 12.40 & 19 & 92 \\
\hline Age & Non-borrowing households & 8,142 & 49 & 14.43 & 11 & 99 \\
\hline I ohorere & Borrowing households & 1,260 & 3 & 1.25 & 1 & 9 \\
\hline Laborers & Non-borrowing households & 8,142 & 3 & 1.18 & 0 & 9 \\
\hline & Borrowing households & 1,260 & 1 & 0.28 & 0 & 1 \\
\hline Education & Non-borrowing households & 8,142 & 1 & 0.25 & 0 & 1 \\
\hline & Borrowing households & 1,260 & 1 & 0.36 & 0 & 1 \\
\hline Rural & Non-borrowing households & 8,142 & 1 & 0.46 & 0 & 1 \\
\hline $\mathrm{R}$ & Borrowing households & 1,260 & 0 & 0.37 & 0 & 1 \\
\hline Kegion & Non-borrowing households & 8,142 & 0 & 0.48 & 0 & 1 \\
\hline$K$ inh & Borrowing households & 1,260 & 1 & 0.49 & 0 & 1 \\
\hline Kinh & Non-borrowing households & 8,142 & 1 & 0.35 & 0 & 1 \\
\hline & Borrowing households & 1,260 & 165,295 & 277,159 & 5,000 & $3,764,100$ \\
\hline Asset & Non-borrowing households & 8,142 & 491,331 & $1,132,588$ & 0 & $3.07 \mathrm{E}+07$ \\
\hline
\end{tabular}

Source: Authors' calculation based on 2010 VHLSS data.

Notes: This table reports the basic descriptive statistics of the variables we use in this article. Column (1) presents the variable names and the classification of two groups. Column (2) reports the number of observations in each group. Columns (3) and (4) demonstrate the values of mean and standard deviation respectively, while columns (5) and (6) indicate the minimum and maximum values of variables. 
Table 4. Correlation Matrix of Variables

\begin{tabular}{c|c|c|c|c|c|c|c|c|c}
\hline \hline & Income & Debt & Age & Laborers & Education & Rural & Region & Kinh & Asset value \\
\hline$(1)$ & $(2)$ & $(3)$ & $(4)$ & $(5)$ & $(6)$ & $(7)$ & $(8)$ & $(9)$ & $(10)$ \\
\hline Income & 1.0000 & & & & & & & & \\
\hline Debt & $-0.0379^{* *}$ & 1.0000 & & & & & & & \\
\hline Age & -0.0113 & $-0.0989^{* *}$ & 1.0000 & & & & & & \\
\hline Laborers & $0.0681^{* *}$ & $0.0504^{* *}$ & $0.2149^{* *}$ & 1.0000 & & & & & \\
\hline Education & $0.0443^{* *}$ & $-0.0240^{*}$ & $-0.0997^{* *}$ & $0.1756^{* *}$ & 1.0000 & & & & \\
\hline Rural & $-0.0234^{*}$ & $0.1104^{* *}$ & $-0.0611^{* *}$ & $-0.0222^{*}$ & $-0.0840^{* *}$ & 1.0000 & & & \\
\hline Region & $0.0387^{* *}$ & $-0.1500^{* *}$ & $0.0511^{* *}$ & -0.0324 & $0.0777^{* *}$ & $-0.1132^{* *}$ & 1.0000 & & \\
\hline Kinh & $0.0568^{* *}$ & $-0.2465^{* *}$ & $0.1570^{* *}$ & $-0.0372^{* *}$ & $0.1099^{* *}$ & $-0.1677^{* *}$ & $0.2679^{* *}$ & 1.0000 & \\
\hline Asset value & $0.1202^{* *}$ & $-0.1043^{* *}$ & $0.0707^{* *}$ & $0.0885^{* *}$ & $0.0829^{* *}$ & $-0.3152^{* *}$ & $0.2501^{* *}$ & $0.1356^{* *}$ & 1.0000 \\
\hline \hline
\end{tabular}

Source: Authors' calculation based on 2010 VHLSS data.

Notes: This table reports the correlation matrix of variables we use in the article. Column (1) lists all the variables that we explore in the empirical-results section, while columns (2) through (10) report the values of the correlation level of each pair of variables. The * and * denote the significance at 95 and 99 percent confidence levels.

Table 5. Relationship Between Income and Loans

\begin{tabular}{c|c|c|c}
\hline \hline & Borrowed & Non-borrowed & $\mathbf{t}$ \\
\hline No. of obs. & 1,260 & 8,142 & \\
\hline Mean & 42,037 & 71,642 & $-3.6809^{* *}$ \\
\hline Mean std. error & 2,406 & 3,142 & \\
\hline Std. dev. & 85,389 & 283,501 & \\
\hline \hline
\end{tabular}

Source: Authors' calculation based on 2010 VHLSS data.

Notes: This table demonstrates the association between household income and households' borrowing status. The ** denotes the significance at 99 percent confidence level. The main hypothesis is the difference between mean income of borrowing households and that of non-borrowing ones. The t-test hypothesis is as follows: $H_{0}$ : difference $=0$, and $H_{a}$ : difference $<0$ (see Table 2 and Table 3 for details on the data sample).

Table 6. Cross-Tabulation of Loans and Geographical Location of Households

\begin{tabular}{c|c|c|c}
\hline \hline & Borrowed & Non-borrowed & Total \\
\hline Rural & $1,062(84.3 / 15.7)$ & $5,688(69.9 / 84.3)$ & 6,750 \\
\hline Urban & $198(15.7 / 07.5)$ & $2,454(30.1 / 92.5)$ & 2,652 \\
\hline Total & 1,260 & 8,142 & 9,402 \\
\hline \hline
\end{tabular}

Source: Authors' calculation based on 2010 VHLSS data.

Notes: Column/row percentages in parentheses (in that order). The table geographically presents the number of borrowing and non-borrowing households. Percentage figures are in parentheses (see Table 2 and Table 3 for details on the data sample). 
Table 7. Geographical Disparity in Household Income

\begin{tabular}{c|c|c|c}
\hline \hline & Rural & Urban & $\mathbf{t}$ \\
\hline Number of observations & 6,570 & 2,649 & \\
\hline Mean & 63,794 & 77,626 & $-2.2695^{*}$ \\
\hline Mean std. error & 3,306 & 4,865 & \\
\hline Std. dev. & 271,654 & 250,399 & \\
\hline \hline
\end{tabular}

Source: Authors' calculation based on 2010 VHLSS data.

Notes: This table presents the disparity between household income and households' location of residence. The * denotes significance at 95 percent confidence level. The main hypothesis is the difference between mean income of rural and urban households. The t-test hypothesis is as follows: $H_{0}$ : difference $=0$, and $H_{a}$ : difference $<0$ (see Table 2 and Table 3 for details on the data sample).

Table 8. Results from Probit Regression: Probability of Households Getting Access to Preferential Loans

\begin{tabular}{c|c|c}
\hline \hline Explanatory variables & Coefficients & Average marginal effects \\
\hline \multirow{2}{*}{ Age } & $-0.0089^{* *}$ & $-0.0017^{* *}$ \\
& $(0.0014)$ & $(0.0002)$ \\
\hline \multirow{2}{*}{ No. of household laborers } & $0.1046^{* *}$ & $0.0203^{* *}$ \\
& $(0.0151)$ & $(0.0029)$ \\
\hline \multirow{2}{*}{ Education } & 0.0145 & 0.0028 \\
& $(0.0666)$ & $(0.0126)$ \\
\hline \multirow{2}{*}{ Rural } & $0.1009^{*}$ & $0.0196^{*}$ \\
& $(0.0466)$ & $(0.0092)$ \\
\hline \multirow{2}{*}{ Region } & $-0.2531^{* *}$ & $-0.0492^{* *}$ \\
& $(0.0432)$ & $(0.0083)$ \\
\hline \multirow{2}{*}{ Kinh ethnicity } & $-0.5721^{* *}$ & $-0.1112^{* *}$ \\
& $(0.0416)$ & $(0.0078)$ \\
\hline \multirow{2}{*}{ Total asset value } & $-0.5040^{* *}$ & $-0.0979^{* *}$ \\
& $(0.0634)$ & $(0.0164)$ \\
\hline \multirow{2}{*}{ Intercept } & $-0.4383^{* *}$ & - \\
& $(0.0994)$ &
\end{tabular}

Source: Authors' calculation based on 2010 VHLSS data.

Notes: Standard errors are in parentheses. The dependent variable is the probability of getting access to preferential loans. The number of observations is 9,402 . The * and ** denote the significance at 95 and 99 percent confidence levels. Wald Chi ${ }^{2}(7)$ $=579.04^{* *} ; R^{2}=10.41 \%$ (see Table 2 and Tables 3 for details on the data sample). 
Table 9. Results from Quantile Regression: Determinants of Household Income

\begin{tabular}{|c|c|c|c|c|}
\hline \multirow{2}{*}{ Explanatory variables } & \multicolumn{3}{|c|}{ Quantile regression } & \multirow{2}{*}{$\begin{array}{c}\text { Linear } \\
\text { regression }\end{array}$} \\
\hline & 25 th & 50th & 75 th & \\
\hline Debt & $\begin{array}{c}-0.1347^{* *} \\
(0.0443)\end{array}$ & $\begin{array}{c}-0.2166^{* *} \\
(0.0329)\end{array}$ & $\begin{array}{c}-0.2729^{* *} \\
(0.0431)\end{array}$ & $\begin{array}{c}-0.2450^{* *} \\
(0.0367)\end{array}$ \\
\hline Age & $\begin{array}{c}-0.0227^{* *} \\
(0.0019)\end{array}$ & $\begin{array}{c}-0.0204^{* *} \\
(0.0014)\end{array}$ & $\begin{array}{c}-0.0177^{* * *} \\
(0.0019)\end{array}$ & $\begin{array}{c}-0.0216^{* *} \\
(0.0012)\end{array}$ \\
\hline $\begin{array}{l}\text { No. of household } \\
\text { laborers }\end{array}$ & $\begin{array}{l}0.3321^{* *} \\
(0.0151)\end{array}$ & $\begin{array}{l}0.2884^{* *} \\
(0.0119)\end{array}$ & $\begin{array}{l}0.2590^{* *} \\
(0.0143)\end{array}$ & $\begin{array}{l}0.3236^{* *} \\
(0.0124)\end{array}$ \\
\hline Education & $\begin{array}{l}0.6729^{* *} \\
(0.0872)\end{array}$ & $\begin{array}{l}0.4799^{* *} \\
(0.0604)\end{array}$ & $\begin{array}{l}0.4244^{* *} \\
(0.0727)\end{array}$ & $\begin{array}{l}0.5677^{* *} \\
(0.0588)\end{array}$ \\
\hline Rural & $\begin{array}{c}-0.2214^{* *} \\
(0.0417)\end{array}$ & $\begin{array}{l}-.2970^{* *} \\
(0.0536)\end{array}$ & $\begin{array}{c}-0.2789^{* *} \\
(0.0435)\end{array}$ & $\begin{array}{c}-0.2521^{* *} \\
(0.0428)\end{array}$ \\
\hline Kinh & $\begin{array}{c}0.2786^{* *} \\
(0.0384)\end{array}$ & $\begin{array}{l}0.4148^{* *} \\
(0.0338)\end{array}$ & $\begin{array}{l}0.5302^{* *} \\
(0.0324)\end{array}$ & $\begin{array}{l}0.3734^{* *} \\
(0.0332)\end{array}$ \\
\hline Total asset value & $\begin{array}{l}0.1270^{* *} \\
(0.0409)\end{array}$ & $\begin{array}{l}0.2620 * * \\
(0.0605)\end{array}$ & $\begin{array}{l}0.5200^{* *} \\
(0.0550)\end{array}$ & $\begin{array}{l}0.2150 * * \\
(0.0360)\end{array}$ \\
\hline Intercept & $\begin{array}{l}9.0982^{* *} \\
(0.1376)\end{array}$ & $\begin{array}{l}9.9605^{* *} \\
(0.1006)\end{array}$ & $\begin{array}{c}10.5065^{* *} \\
(0.1537)\end{array}$ & $\begin{array}{l}9.7799 * * \\
(0.0899)\end{array}$ \\
\hline $\mathrm{R}^{2}$ & $9.43 \%$ & $10.09 \%$ & $11.90 \%$ & $17.15 \%$ \\
\hline
\end{tabular}

Source: Authors' calculation based on 2010 VHLSS data

Notes: The dependent variable is the logarithm of income. The ** denotes significance at 99 percent confidence level. The number of observations is reduced to 7,913 because of the elimination of zero-income households (see Table 2 and Table 3 for details on the data sample). Bootstrap standard error is in parentheses for the 25th, 50th, and 75th quantile regression columns. Robust standard error is in parentheses in the linear regression column.

\section{APPENDICES}

Table 1A. Financial Programs in Rural Finance in Vietnam

\begin{tabular}{|c|c|c|c|}
\hline Project & Partner & $\begin{array}{l}\text { Million } \\
\text { USD }\end{array}$ & Timeline \\
\hline \multicolumn{4}{|c|}{ Donor: World Bank } \\
\hline $\begin{array}{l}\text { Second northern mountains poverty } \\
\text { reduction project }\end{array}$ & $\begin{array}{l}\text { Provinces and ministry } \\
\text { of planning and } \\
\text { investment }\end{array}$ & 165.0 & $\begin{array}{l}06 / 4 / 2010- \\
30 / 6 / 2015\end{array}$ \\
\hline Rural finance project I, II, III & $\begin{array}{l}\text { Bank for investment } \\
\text { and development } \\
\text { (BIDV) }\end{array}$ & 548 & $\begin{array}{c}2008- \\
21 / 12 / 2013\end{array}$ \\
\hline \multicolumn{4}{|l|}{ Donor: Asian Development Bank } \\
\hline $\begin{array}{l}\text { TA 3741-VIE - Preparing the framework for } \\
\text { microfinance development (SBV) }\end{array}$ & & 0.30 & $2001-2004$ \\
\hline $\begin{array}{l}\text { TA } 3638 \text { VIE- implementing the regulatory } \\
\text { and supervisory framework for microfinance }\end{array}$ & & 0.25 & $2007-2008$ \\
\hline $\begin{array}{l}\text { JFPR 9140-VIE - Formalizing microfinance } \\
\text { institutions (SBV) }\end{array}$ & & 1.65 & $2009-2011$ \\
\hline $\begin{array}{l}\text { TA 7499-VIE - Preparing microfinance } \\
\text { sector development program for Vietnam } \\
\text { (SBV) }\end{array}$ & & 0.75 & $2010-2011$ \\
\hline Microfinance Sector Development Program & State Bank of Vietnam & 0.5 & $21 / 02 / 2010$ \\
\hline $\begin{array}{l}\text { Microfinance development program } \\
\text { Subprogram } 1\end{array}$ & State Bank of Vietnam & 40 & $05 / 7 / 2012$ \\
\hline Building a sustainable microfinance sector & & 0.04 & $2010-2011$ \\
\hline
\end{tabular}




\begin{tabular}{|c|c|c|c|}
\hline $\begin{array}{l}\text { through strengthening the } \mathrm{VN} \text { microfinance } \\
\text { working group }\end{array}$ & & & \\
\hline Loan to support CCF/PCF operations & CCF/PCF & 39 & \\
\hline $\begin{array}{l}\text { Technical assistance grant to CCF/PCF for } \\
\text { training, study tours and studies }\end{array}$ & $\mathrm{CCF} / \mathrm{PCF}$ & 0.50 & $2010-2012$ \\
\hline $\begin{array}{l}\text { Technical assistance program state bank of } \\
\text { Vietnam microfinance support Program }\end{array}$ & State Bank of Vietnam & 1.37 & $2010-2013$ \\
\hline Microfinance support program VN & & 0.04 & $2010-2011$ \\
\hline $\begin{array}{l}\text { Building a sustainable microfinance sector } \\
\text { through strengthening the Vietnam } \\
\text { microfinance working group (MFWG) }\end{array}$ & & 0.50 & $2010-2012$ \\
\hline $\begin{array}{l}\text { AECID - ICO microfinance project of } \\
\text { Spanish government (PCF) }\end{array}$ & & 24.14 & $2006-2018$ \\
\hline $\begin{array}{l}\text { Country micro-entrepreneur of the year } \\
\text { award }\end{array}$ & & 0.07 & 2010 \\
\hline $\begin{array}{l}\text { Linking rural areas - urban areas to } \\
\text { eliminate hunger and reduce poverty (PCF) }\end{array}$ & & 3.60 & $\begin{array}{l}2008 \\
2010\end{array}$ \\
\hline $\begin{array}{l}\text { Project on supporting VBSP to formulate } \\
\text { development strategy (project beyond WTO } \\
\text { I) }\end{array}$ & & 0.07 & $2007-2008$ \\
\hline $\begin{array}{l}\text { VBARD microfinance development strategy } \\
\text { (RFD11) }\end{array}$ & & 0.02 & 2007 \\
\hline Technical assistance project of policy & & 0.42 & $2003-2006$ \\
\hline $\begin{array}{l}\text { Project "Supporting the Extension of Savings } \\
\text { Service for the Poor" }\end{array}$ & & 0.30 & $2007-2010$ \\
\hline
\end{tabular}

Source: International Fund for Agricultural Development 2012.

Table 2A. Total ODA for Vietnam between 1991 and 2011

\begin{tabular}{c|c|c|c}
\hline \hline Year & Total ODA & Preferential loans & Non-refundable ODA \\
\hline 1991 & 1.60 & - & 1.60 \\
\hline 1993 & 2.86 & - & 2.86 \\
\hline 1994 & 2.43 & - & 2.43 \\
\hline 1995 & 13.99 & - & 13.99 \\
\hline 1996 & 13.34 & - & 13.34 \\
\hline 1997 & 2.10 & - & 2.10 \\
\hline 1998 & 5.60 & - & 5.60 \\
\hline 1999 & 2.67 & - & 2.67 \\
\hline 2000 & 3.10 & - & 3.10 \\
\hline 2001 & 9.48 & - & 9.48 \\
\hline 2002 & 1.88 & - & 1.88 \\
\hline 2003 & 96.30 & 74.68 & 21.63 \\
\hline 2004 & 7.94 & 2.81 & 5.13 \\
\hline 2005 & 22.89 & 0.00 & 22.89 \\
\hline 2006 & 68.88 & 65.90 & 2.98 \\
\hline 2007 & 1.60 & 0.00 & 1.60 \\
\hline 2008 & 102.44 & 80.00 & 22.44 \\
\hline 2009 & 356.02 & 320.00 & 36.02 \\
\hline 2010 & 75.87 & 75.00 & 0.87 \\
\hline 2011 & 0.29 & 0.00 & 0.29 \\
\hline \hline
\end{tabular}

Source: Vietnam Bank for Social Policy 2012 
Table 3A. Household Income Distribution (Thousand VND)

\begin{tabular}{c|c|c}
\hline \hline & Borrowing & Non-borrowing \\
\hline Mean & $42,037.16$ & $71,642.16$ \\
\hline Quantile & & \\
\hline Median (50th Quantile) & $23,057.00$ & $25,175.00$ \\
\hline 25th Quantile & $11,790.00$ & $4,720.00$ \\
\hline 75th Quantile & $44,506.50$ & $64,880.00$ \\
\hline 95th Quantile & $1,778,615.00$ & $16,800,000$ \\
\hline No. of obs. & 1,260 & 8,142 \\
\hline \hline
\end{tabular}

Source: Authors' calculation based on 2010 VHLSS data.

Table 4A. Household Ownership Rates of Durables in 1998 and 2010 (Percent)

\begin{tabular}{c|c|c|c|c|c|c}
\hline \hline \multirow{2}{*}{ Items } & \multicolumn{2}{|c|}{ National } & \multicolumn{2}{c|}{ Poor } & \multicolumn{2}{c}{ Extremely poor } \\
\cline { 2 - 7 } & 1998 & $\mathbf{2 0 1 0}$ & $\mathbf{1 9 9 8}$ & $\mathbf{2 0 1 0}$ & 1998 & 2010 \\
\hline Car & 0.2 & 1.3 & 0.0 & 0.0 & 0.0 & 0.0 \\
\hline Motorbike & 20.3 & 75.9 & 2.4 & 50.9 & 0.4 & 39.6 \\
\hline Mobile phone & - & 69.8 & - & 37.1 & - & 24.2 \\
\hline Television & 55.7 & 89.3 & 30.2 & 73.6 & 11.0 & 61.3 \\
\hline Computer & 0.7 & 16.8 & 0.0 & 0.3 & 0.0 & 0.4 \\
\hline Refrigerator & 9.0 & 42.6 & 0.0 & 5.3 & 0.0 & 2.2 \\
\hline Air conditioner & 0.7 & 8.2 & 0.0 & 0.1 & 0.0 & 0.2 \\
\hline Electric fan & 68.4 & 85.2 & 45.9 & 65.2 & 26.3 & 49.4 \\
\hline Rice cooker or electric stove & 19.3 & 77.6 & 1.1 & 45.6 & 0.0 & 28.3 \\
\hline \hline
\end{tabular}

Source: Authors' calculation based on 2010 VHLSS data 